\title{
New data of eskolaite, Zn-bearing chromite, willyamite and ullmannite from the Outokumpu mine, eastern Finland
}

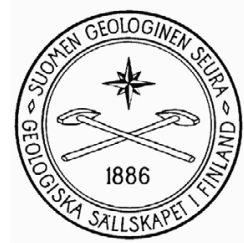

\author{
Thorolf W. Weiser ${ }^{1)}$, Kari K. Kojonen ${ }^{2) *}$ and Jerzy LodziaK ${ }^{1)}$ \\ 1) Federal Institute for Geosciences and Natural Resources, P.O. Box 510153, \\ D-30631 Hannover, Germany \\ 2) Geological Survey of Finland, P.O. Box 96, FIN-02151 Espoo, Finland
}

\begin{abstract}
Two massive sulphide ore samples from the Outokumpu mine, eastern Finland, were studied by ore microscopy and electron microprobe analysis. The main minerals are pyrrhotite, pentlandite, chalcopyrite, and sphalerite with accessory galena and molybdenite. The matrix contains euhedral crystals of homogeneous or zoned eskolaite with variation of $\mathrm{Cr}$ and $\mathrm{Al}$. $\mathrm{Zn}$-bearing-chromite, occuring in sulphide or silicate matrix, is mainly zoned with a clear variation between $\mathrm{Fe}$ and $\mathrm{Mg}+\mathrm{Zn}$ and between $\mathrm{Cr}$ and Al.Very rare are willyamite and ullmannite as inclusions in sulphides. Previously unpublished electron microprobe analyses are presented of eskolaite, Zn-chromite, willyamite and ullmannite. The crystallisation equilibrium temperatures for eskolaite are estimated for the dark zones as ca. $600^{\circ} \mathrm{C}$ and for the light zones ca. $400^{\circ} \mathrm{C}$. The chromite grains are zoned with high $\mathrm{Zn}$ contents derived from the $\mathrm{Zn}$-bearing sulphide ore during cooling of the sulphides and metamorphism. The occurrence of willyamite and ullmannite suggests their crystallization below $550^{\circ} \mathrm{C}$.
\end{abstract}

Key words: massive sulfide deposits, ore minerals, eskolaite, chromite, uraninite, willyamite, ullmannite, chemical composition, electron probe data, Proterozoic, Outokumpu, Finland

*Corresponding author email: kari.kojonen@gtk.fi

\section{Introduction}

Eskolaite is a rare mineral. It was first observed in 1949 from Outokumpu mine, eastern Finland $\left(60^{\circ} 44^{\prime} \mathrm{N}\right.$ latitude and $29^{\circ} 00^{\prime}$ longitude) and later characterized as a new mineral by Kouvo \& Vuorelainen (1958). In the meantime it is described from five other localities worldwide. Milton \& Chao (1958) and Milton \& Narain (1969) found eskolaite as a major constituent in merumite, a complex mixture of several chromium minerals, in gravels of the Merume River, Guyana. The eskolaite from County Wicklow, Ireland is submicroscopic. It occurs around quartz grains and in the matrix of greywacke and could be only identified by XRD (Oppenheim et al., 1977). Forster (1960) described eskolaite in association with chromite from gold occurrences in the Lowveld, northeast Transvaal, South Africa. Cassedanne \& Cassedanne (1980) found eskolaite as a rare component from the alluvium of the Chapada Diamantina in Bahia, Brazil. Karpenko \& Tištšenko (1992) described the mineral from concentrates of core samples from the Belomor-Kuloiian plateau, Arkhangelsk region, Russia. Eskolaite was first analysed using wet chemical meth- 
ods by Kouvo \& Vuorelainen (1958). First electron microprobe analyses were published by von Knorring et al. (1986) and recently by Peltonen et al. (1996), all from the Outokumpu mine. The aim of this paper is mainly to study the chemical composition of eskolaite and its variation.

We will also present new analytical data of Zn-bearing chromite and previously unreported willyamite, ullmannite and uraninite from the Outokumpu ore. Zn-bearing chromite was first described by Thayer et al. (1964) from chromite dykes cutting diopside skarns (Vähätalo, 1953) from the Outokumpu mine. Later, Zn-bearing chromite was also found inside the sulphide ore body (Weiser, 1966, 1967).

In 1997, the senior author received two massive ore samples from Outokumpu mine of the Natural history museum of the University of Helsinki (B 6384 and B 6379) labelled as eskolaite, and eskolaite and cobalt pentlandite, respectively. The samples were studied by ore microscopy and electron microprobe (EMP) at the Federal Institute for Geosciences and Natural Resources, Hannover, Germany.

\section{Analytical methods}

Two polished sections of each sample were studied with a polarizing microscope Leica DMRB in reflected light in air and oil immersion (Standard Immersion Oil, $\mathrm{n}=1.5$ ) and photographed with Kodak Professional film 5018 EPY.

The minerals were analyzed with a Camebax Microbeam EMP with $20 \mathrm{kV}$ accelerating voltage, and $30 \mathrm{nA}$ specimen current. The standards and X-ray lines for eskolaite and chromite were: $\mathrm{Cr} \mathrm{K \alpha}$ (eskolaite and chromite), $\mathrm{Fe} \mathrm{K} \alpha, \mathrm{Al} \mathrm{K} \alpha, \mathrm{Mg} \mathrm{K} \alpha$ (chromite), $\mathrm{Zn} \mathrm{K} \alpha$ (gahnite), Ni Ka (bunsenite), Mn K $\alpha$ and $\mathrm{Ti} \mathrm{K} \alpha$ (pyrophanite), $\mathrm{V} \mathrm{K \alpha}$ (metal and vanadinite). The measuring times were in eskolaite $10 \mathrm{~s}$ for $\mathrm{Cr}$ and $20 \mathrm{~s}$ for other elements, in chromite $10 \mathrm{~s}$ for $\mathrm{Cr}, \mathrm{Al}, \mathrm{Fe}, \mathrm{Mg}$, and $20 \mathrm{~s}$ for other elements. The following X-ray lines and standards were used for sulphides and sulphosalts: $\mathrm{Fe} \mathrm{K} \alpha$ and $\mathrm{S} \mathrm{K} \alpha$ (synthetic pyrrhotite), $\mathrm{Zn} \mathrm{K} \alpha$ (sphalerite), $\mathrm{Cu} \mathrm{K} \alpha$ (chalcopyrite), Ni K $\alpha$, Co K $\alpha$, Cd L $\alpha$, Se L $\alpha$, Te L $\alpha$ (metal), Sb
$\mathrm{L} \alpha$ (stibnite), As $\mathrm{L} \alpha$ (synthetic galliumarsenide). The measuring time were for the main elements $10 \mathrm{~s}$, for $\mathrm{Sb}, \mathrm{As}$, Se and Te $20 \mathrm{~s}$, and for Cd in sphalerite $30 \mathrm{~s}$. Raw data were corrected using the PAP program supplied by CAMECA. Detection limits of the analyzed elements were 0.05 wt.\%. In total, $104 \mathrm{EMP}$ analyses were carried out on the various types of ore minerals in sample B 6384 and sample B 6379.

\section{Results}

\section{I. Description of the samples}

Specimen B 6384 is a massive sulphide ore sample from the Outokumpu mine, Outokumpu. The main ore minerals are mainly coarse-grained intergrown pyrrhotite and chalcopyrite. All other observed ore minerals occur as inclusions in pyrrhotite and/or chalcopyrite. Conspicuous is the frequent occurrence of eskolaite. The grains are mainly euhedral single crystals up to several $100 \mu \mathrm{m}$ across. Eskolaite is grey with a bluish tinge, especially in oil. The reflection pleochroism in air is weak, more noticeable in oil. The anisotropy is weak, but clearly recognizable, with blue colour in air and more brownish in oil. Internal reflections could not be observed. The majority of the crystals show, especially under oil immersion, a clear zoning with light bluish and darker brownish-grey colours (Fig. 1a-f). This zoning is also clearly seen in back-scattered electron images (Fig. 2a-f). Inclusions in eskolaite are small droplets of pyrrhotite and galena and needle-like grains of chalcopyrite. A droplet of ullmannite, intergrown with chalcopyrite, could be observed in one eskolaite grain. Cracks and cavities can be filled with fine-grained graphite. Some eskolaite grains show a marginal alteration, which can also start from cracks and catch inner parts of the crystals. Microprobe analyses of this material showed same elements as in eskolaite, but low totals. Presumably it is hydrous chromium oxide. In contrast to eskolaite only one chromite grain could be found in sample B 6384. It is a euhedral homogeneous single crystal $150 \mu \mathrm{m}$ across without any inclusions and surrounded by silicate (Fig. 3a, 3b). Pentlandite is very common in the polished sections 
of sample B 6384 and occurs as two types. The first type consists of irregularly distributed subidiomorphic grains up to some hundred microns. The second type are flame-like exsolution lamellae on grain boundaries of pyrrhotite. Sphalerite is also very common as rounded xenomorphic grains up to $200 \mu \mathrm{m}$ in size. Under the ore microscope sphalerite shows in oil immersion reddish internal reflections. The droplike grain of ullmannite, intergrown with chalcopyrite, occurs as inclusion in eskolaite. It is of white colour and shows very high reflectivity and weak anisotropy. Galena could also be detected as inclusions in eskolaite, chalcopyrite or silicate. Fine-grained lamellar graphite is very common occurring as aggregates in silicate, randomly on eskolaite and filling of the cracks in it. Very rare metamictic idiomorphic uraninite grains up to $50 \mu \mathrm{m}$ across are surrounded by thucholite halo in the silicate matrix (Fig. 4). Uraninite has a low reflectivity and is in oil immersion of grey colour with a distinct brownish tinge.

The specimen B 6379 is a massive sulphide ore sample from the stope V22, Outokumpu mine. Coarse-grained pyrrhotite is the main ore mineral that includes all other ore minerals. Pentlandite is very common in the polished sections and occurs, similar to sample B 6384, as two types: as irregularly distributed anhedral grains up to some hundred microns and as typical flame-like exsolution lamellae on grain boundaries of pyrrhotite. Sphalerite is also very common. The xenomorphic grains up to $300 \mu \mathrm{m}$ across occur as inclusions in pyrrhotite or on the boundary between pyrrhotite and silicate. Chalcopyrite occurs as lobate inclusions up to $150 \mu \mathrm{m}$ in pyrrhotite or silicate. Galena occurs as up to 20 $\mu \mathrm{m}$ small single grains irregularly distributed in silicate. Very rare are drop-like grains of ullmannite up to $40 \mu \mathrm{m}$ long as isolated inclusions in pyrrhotite (Fig. 5). Ullmannite is of white colour with a bluish tinge, showing high reflectivity and weak anisotropism. Similar to the optical properties of ullmannite are some up to $60 \mu \mathrm{m}$ long needles in pyrrhotite or on the grain boundary between pyrrhotite and silicate (Fig. 6). The exact identification of these phases is only possible by microprobe analyses (Dobbe, 1991).
The analyses (see below) showed that these grains are the cobalt analogue of ullmannite called willyamite, first described from Broken Hill, Australia (Pittman, 1893). According to our knowledge, this is the first description of willyamite from Outokumpu. Irregular graphite is commonly distributed as grains up to $50 \mu \mathrm{m}$ across. Graphite sometimes contains small laths of molybdenite. Only one euhedral crystal of chromite, $200 \mu \mathrm{m}$ across, could be observed as inclusion in pyrrhotite (Fig. 3c, 3d). The chromite grain is zoned and the inner part of the broken crystal is replaced by silicate. The chromite shows a bluish grey colour, low reflectivity, with light and dark strips and patches. The dark strips show a brownish tinge under oil immersion. They form on two sides of the broken crystal the outer zones whereas the two other sides are light strips and patches. Eskolaite could not be observed in sample B 6379. In the silicate matrix there are a few rounded metamictic grains of uraninite with a thucholite rich halo similar to sample B 6384 .

\subsection{Chemical composition of the ore minerals}

\subsection{Eskolaite}

Sixteen grains of eskolaite of sample B 6384 were analyzed by microprobe. Six grains are homogeneous whereas the other ten are zoned. The homogeneous grains are very similar in their composition with a mean of 64.92 wt.\% Cr, 3.14 wt.\% V, and 0.28 wt.\% $\mathrm{Fe}$ (Table 1). This corresponds to the general formula of $\left(\mathrm{Cr}_{1.90} \mathrm{~V}_{0.09} \mathrm{Fe}_{0.01}\right)_{2} \mathrm{O}_{3}$. Only two grains contain small amounts of $\mathrm{Al}(0.40$ wt.\%). $\mathrm{Mg}, \mathrm{Mn}, \mathrm{Ni}, \mathrm{Zn}$, and Ti could not be detected. This is in good agreement with the results of the wet chemical analysis by Kouvo and Vuorelainen (1958) who found 64.4 wt.\% Cr, $3.11 \mathrm{wt} . \% \mathrm{~V}$, and $0.38 \mathrm{wt} . \% \mathrm{Fe}$, corresponding exactly to the formula of the microprobe analyses. Most of the eskolaite grains show a clear zoning with variable light and dark parallel laths, stripes, or plates in idiomorphic orientation in the microphotographs (Figs. 1a-f), as well as in the BSE images (Fig. 2a-f). Figures 1a and $2 \mathrm{a}$ show a grain with a dark centre surrounded by darker zones and a broad light rim, whereas Figures $1 \mathrm{~b}$ and $2 \mathrm{~b}$ show a crystal with a dark centre 

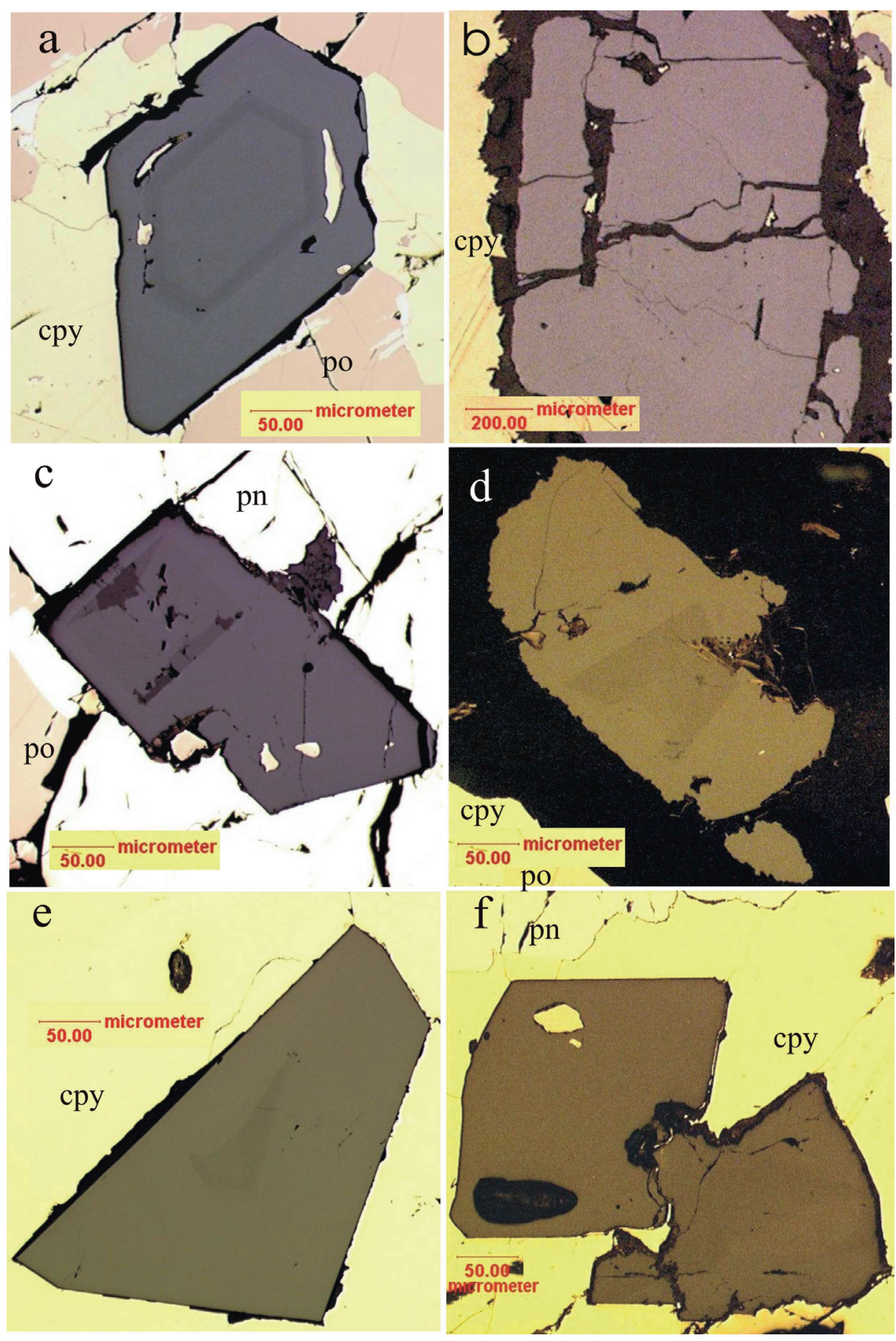

Fig. I. Optical photographs of eskolaite sample B 6384 (plan polarized reflected light, oil immersion). a) Euhedral zoned eskolaite with inclusions of chalcopyrite (yellow) in chalcopyrite (yellow) - pyrrhotite (brownish pink) -matrix (see Fig. 2a). b) Eskolaite with internal euhedral zoning, surrounded by silicate. Small irregular grains of chalcopyrite (yellow) in silicate-filled cracks. On the lower edge of the eskolaite grain a micro-inclusion of galena (white) (see Fig. 2b). c) Partly zoned euhedral eskolaite with inclusions of pyrrhotite (browhnisch pink) and a small rim of silicate - graphite -mixture in pyrrhotite (brownish pink) - pentlandite -matrix (see Fig. 2c). d) Lobate grain of eskolaite with a euhedral zoned core in silicate matrix (see Fig. 2d). e) Euhedral zoned eskolaite in chalcopyrite (yellow) (see Fig. 2e). f) Euhedral homogeneous eskolaite with inclusions of pyrrhotite (brownish pink) intergrown with an anhedral zoned eskolaite in chalcopyrite matrix (yellow) (see Fig. 2f). 


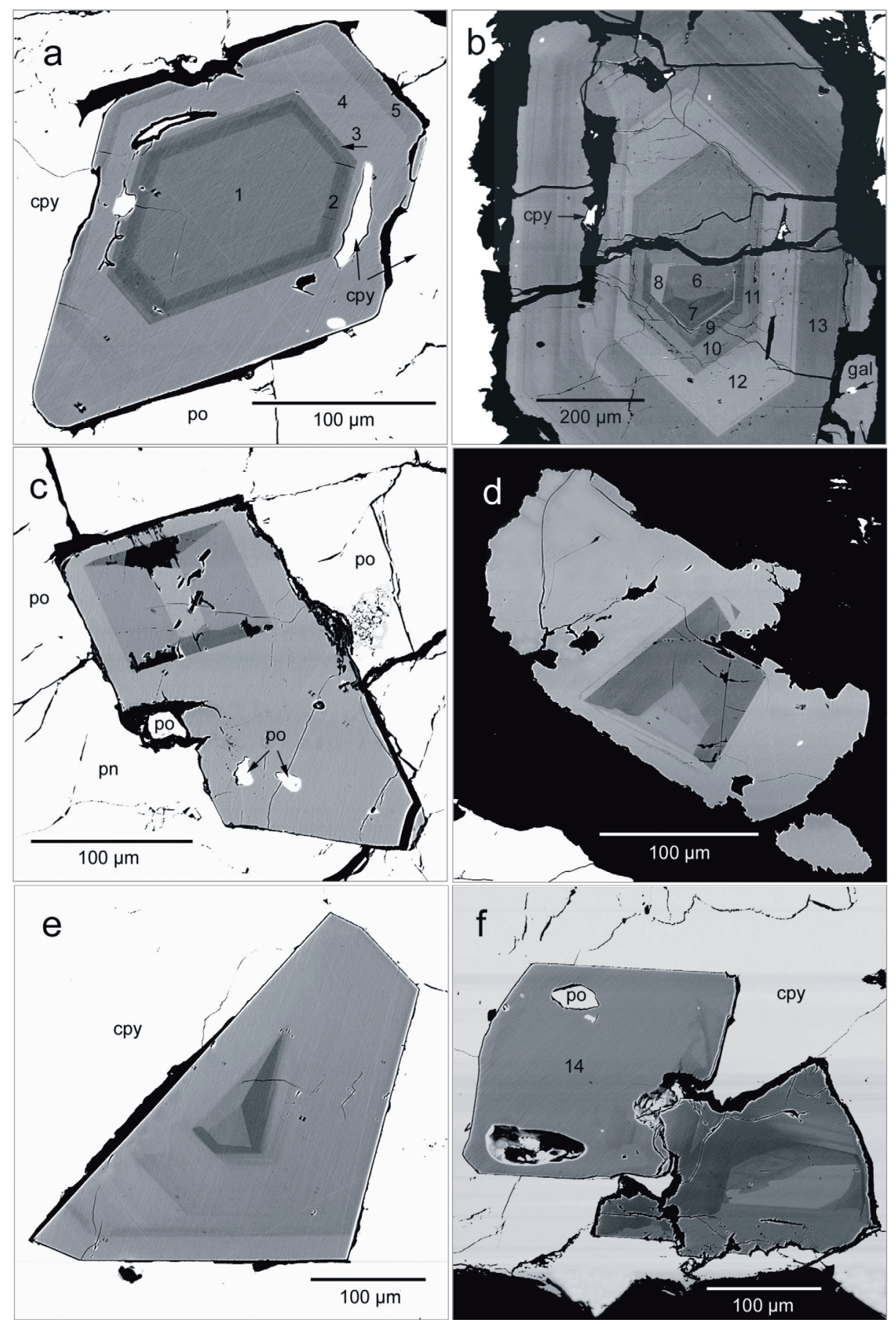

Fig. 2. Back-scattered electron images of eskolaite (sample B 6384). Grain numbers refer to analytical results listed in Table I. a) Euhedaral zoned eskolaite with inclusions of chalcopyrite (cpy) surrounded by pyrrhotite (po) and chalcopyrite (cpy) (grain I). b) Zoned eskolaite with inclusions of chalcopyrite (cpy) and galena (gal) surrounded by silicate (black) (grain 2). c) Partly zoned euhedral eskolaite with inclusions of pyrrhotite (po), surrounded by a small rim of a mixture of silicate and graphite, in pyrrhotite (po) and pentlandite (pn). d) Lobate grain of eskolaite with a zoned core in silicate matrix (black). e) Euhedral zoned eskolaite in chalcopyrite (cpy). f) Euhedral homogeneous eskolaite with inclusion of pyrrhotite (po), intergrown with an anhedral zoned eskolaite in chalcopyrite (cpy) (grain 3). 

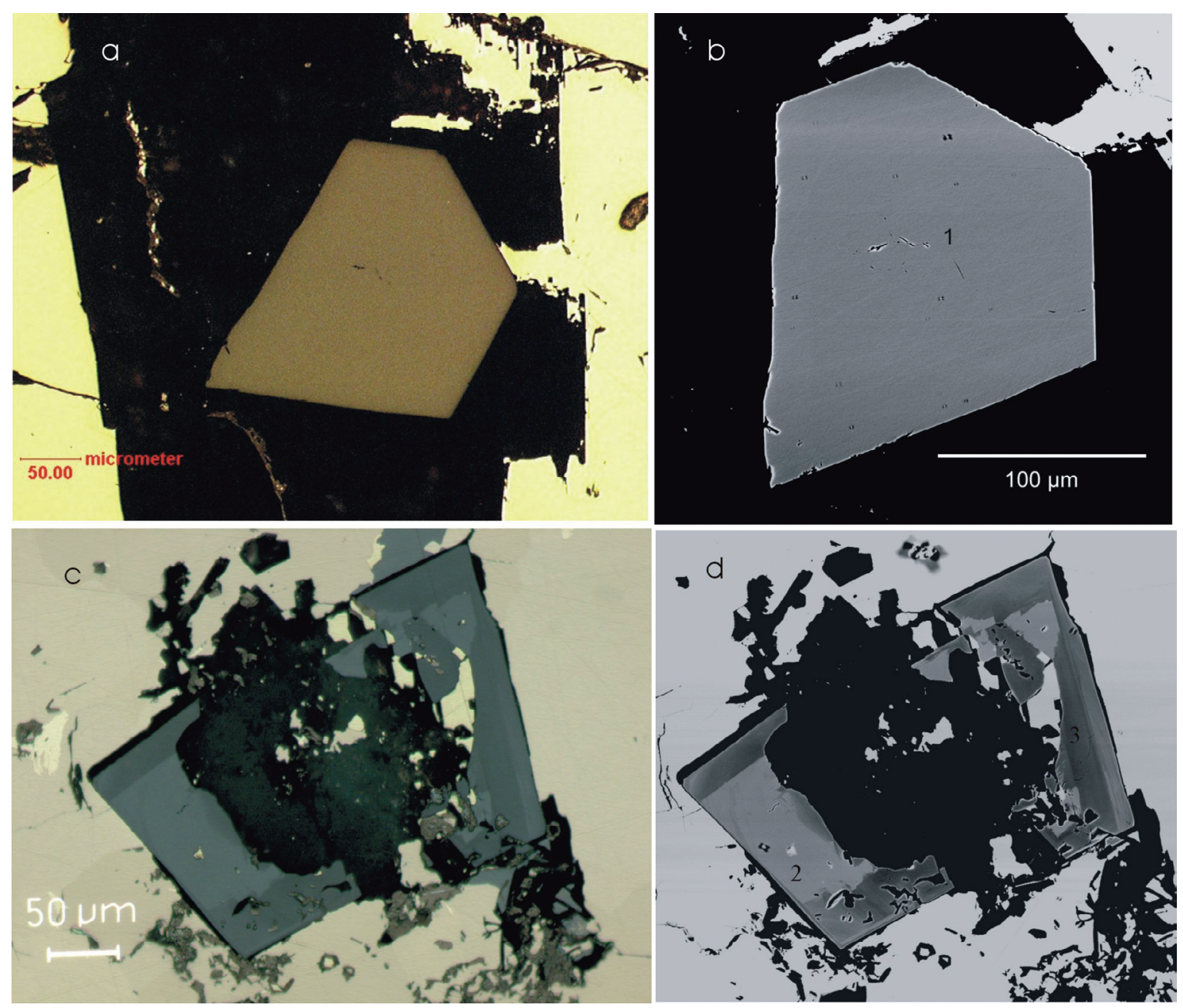

Fig. 3. Zn-bearing chromite grains in Outokumpu ore. $a+b)$ Homogeneous euhedral chromite in silicate gangue between pyrrhotite (brownish pink) and chalcopyrite (yellow). Sample B 6384 (Table 2, no. I). a) oil immersion, b) backscattered electron image. $c+d$ ) Fractured euhedral zoned chromite in pyrrhotite (brownish pink). The inner part is replaced by pyrrhotite (brownish pink) and a mixture of silicate (black) and molybdenite (brown). Sample B 6379 (Table 2, no. 2, 3). c) oil immersion, d) backscattered electron image.

surrounded by several zones with variable brightness and a dark oscillatory rim. Some grains show a zoning only in parts of the crystal (Figures $1 c+2 c, 1 d+$ 2d). The light zones of the eskolaite consist only of $\mathrm{Cr}, \mathrm{V}$, and Fe similar to the homogeneous eskolaite. The darker zones are always characterized by noticeable amounts of $\mathrm{Al}$ (3.45 wt.\%). In some analyses of the darker zones up to 0.77 wt. $\%$ Ti could be detected, $\mathrm{Mg}, \mathrm{Mn}, \mathrm{Ni}$, and $\mathrm{Zn}$ could not be detected in the light or in the dark zones. In general, the follow- ing compositional ranges could be obtained: $58.90-$ 66.29 wt.\% for Cr, $1.94-7.01$ wt.\% for V, 0.18 1.30 wt. $\%$ for $\mathrm{Fe}$, and $0-3.45$ wt. $\%$ for Al. The core of the zoned crystal of Fig. $1 \mathrm{f} / 2 \mathrm{f}$ has a composition of 65.67 wt.\% Cr, 3.19 wt.\% V, and 0.19 wt.\% Fe, corresponding to the formula $\left(\mathrm{Cr}_{1.90} \mathrm{~V}_{0.09} \mathrm{Fe}_{0.01}\right)_{2} \mathrm{O}_{3}$. This is exactly the same composition as the measured homogeneous eskolaite of this sample. However, the rim of this zoned eskolaite contains only 60.64 wt.\% Cr, 3.67 wt.\% V, 0.29 wt.\% Fe, but 2.96 wt.\% 

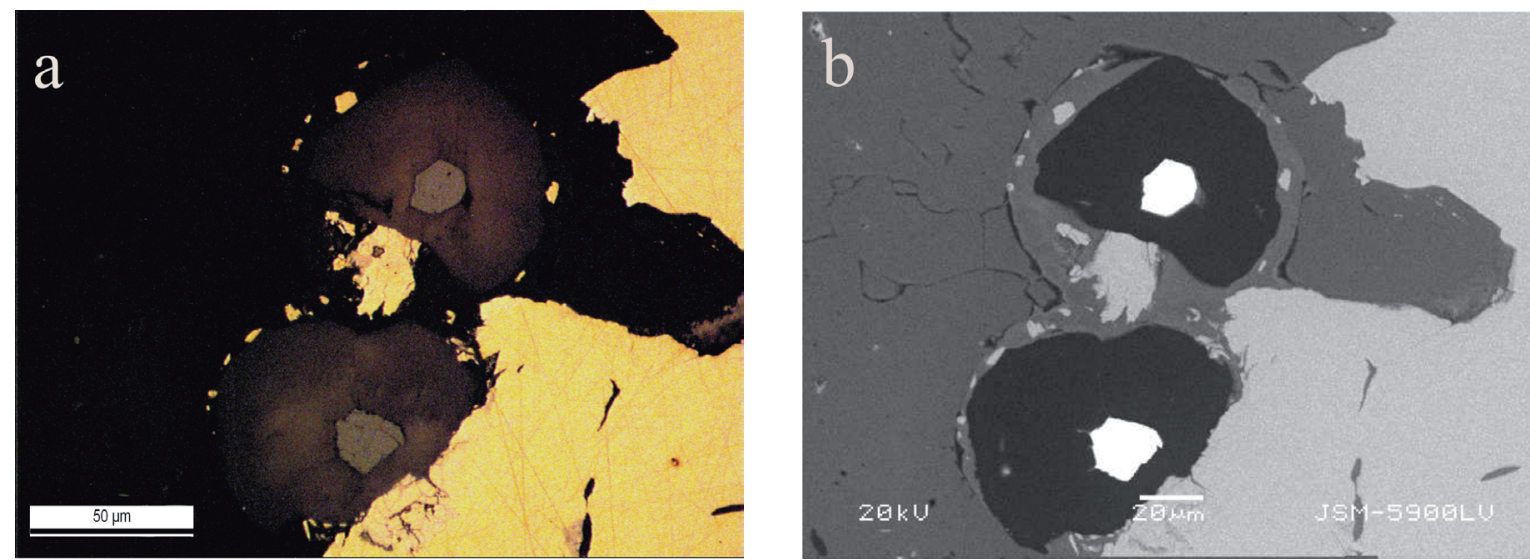

Fig. 4. Uraninite rimmed by a carbon rich halo beside chalcopyrite in silicate matrix (sample B 6384). a) oil immersion, b) back-scattered electron image in polished section.

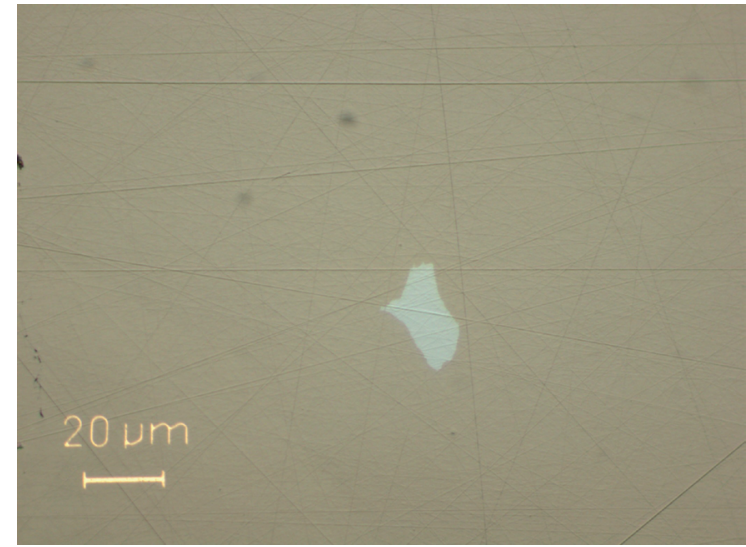

Fig. 5. Ullmannite in pyrrhotite (sample B 6379, oil immersion).

$\mathrm{Al}$ with the formula $\left(\mathrm{Cr}_{1.72} \mathrm{Al}_{0.16} \mathrm{~V}_{0.11} \mathrm{Fe}_{0.01}\right)_{2} \mathrm{O}_{3}$. The composition of the core of the eskolaite grain of Fig. $1 \mathrm{f} / 2 \mathrm{f}$ is similar to the homogeneous outer parts of the grains in Fig. 1c/2c and Fig. 1d/2d. The crystal of Fig. 1a/2a (Table 1, Anal. No. 1-5) shows several light and dark zones which correspond to a variation mainly of $\mathrm{Cr}$ and $\mathrm{Al}$, whereas the concentration of $\mathrm{V}$ and $\mathrm{Fe}$ only in the core is lightly increased. The lowest value of $\mathrm{Cr}$ (58.90 wt.\%), the highest of $\mathrm{Al}$ (3.45 wt.\%) and a high value of V (4.43 wt.\%) could be measured in the dark part of the zoned region of

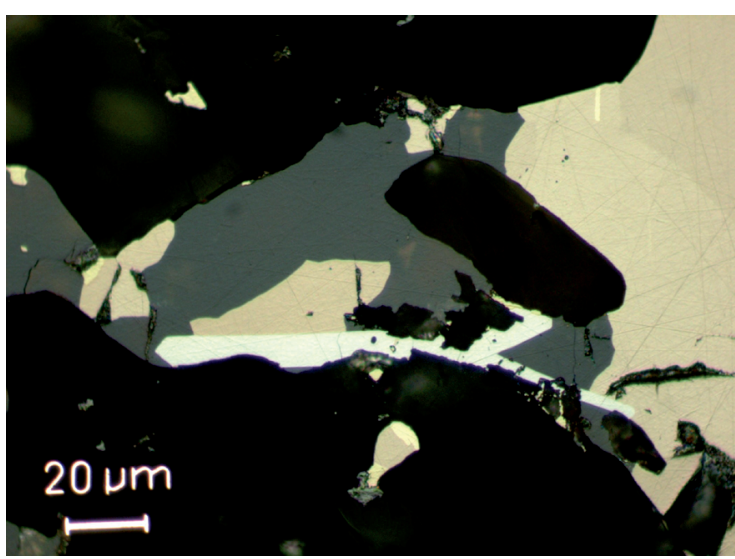

Fig. 6. Willyamite (white) between pyrrhotite (brownish), sphalerite (grey) and silicate (black) (sample B 6379, oil immersion).

the grain of Fig. 1c/2c. The formula corresponds to $\left(\mathrm{Cr}_{1.67} \mathrm{Al}_{0.19} \mathrm{~V}_{0.13} \mathrm{Fe}_{0.01}\right)_{2} \mathrm{O}_{3}$. An unusually high content of $\mathrm{V}(7.01$ wt. \%) together with a high amount of $\mathrm{Fe}$ (0.94 wt.\%) and 0.77 wt.\% $\mathrm{Al}$ could be detected in the lightest part of the zoned region in Fig. $1 \mathrm{~d} / 2 \mathrm{~d}$ suggesting that $\mathrm{V}$ and $\mathrm{Fe}$ can also substitute $\mathrm{Cr}$. The zoning of the eskolaite is characterised by the co-variation of $\mathrm{Cr}$ and $\mathrm{Al}$ (e.g. Fig. 1a/2a, Anal. no. 1-5; Fig. 1b/2b, Anal no. 6-13). However, there is no consistent trend in the compositional changes from core to rim (e.g. Fig. 1a/2a, Fig. 1f/2f). 


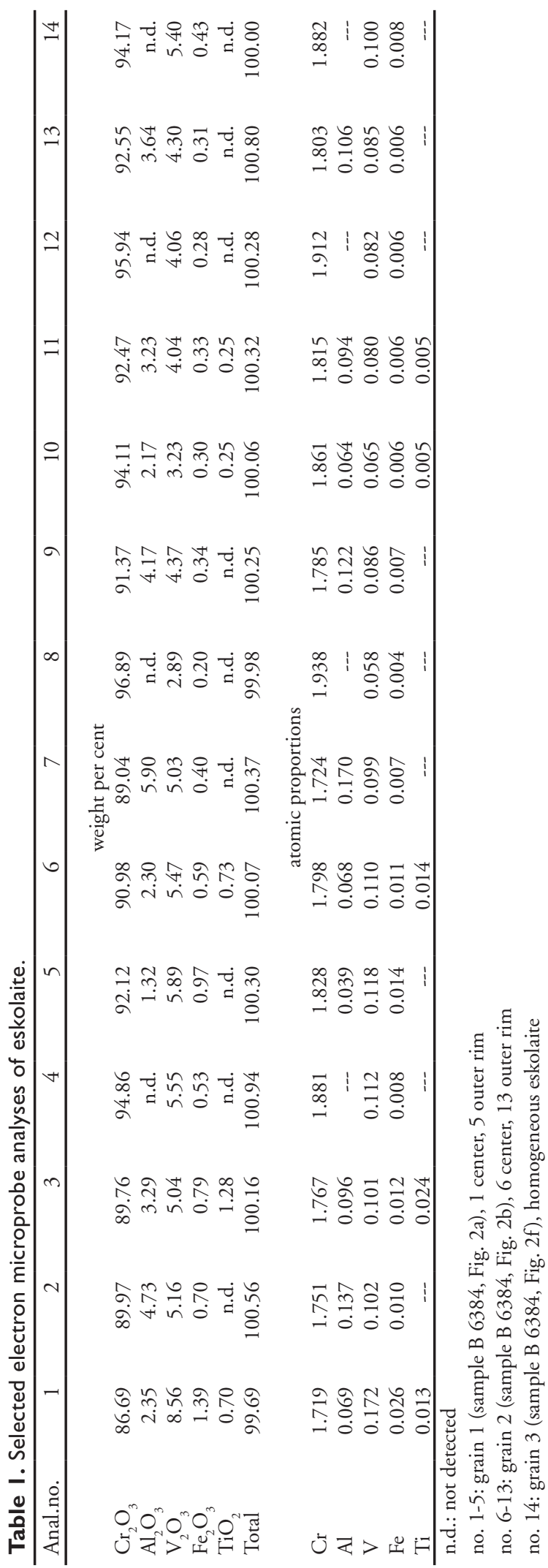

\subsubsection{Chromite}

The chromite of sample B 6384 contains 35.76 wt.\% Cr, 19.92 wt.\% Fe, 10.15 wt.\% V, 4.51 wt. \% Zn, and 2.00 wt.\% Mn, but no Al, Mg, Ni, or Ti. This corresponds to the calculated formula $\left(\mathrm{Fe}_{0.77} \mathrm{Zn}_{0.15} \mathrm{Mn}_{0.08}\right)_{1.00}$ $\left(\mathrm{Cr}_{1.53} \mathrm{~V}_{0.44} \mathrm{Fe}_{0.03}\right)_{2.00} \mathrm{O}_{4}$ (Table 2). The content of $\mathrm{Cr}$ and $\mathrm{Zn}$ is lower and $\mathrm{Fe}$ and $\mathrm{Mn}$ higher than in the zoned chromite of sample B 6379. More conspicuous are the very high content of $\mathrm{V}$ and lack of $\mathrm{Al}$ and $\mathrm{Mg}$. A similar composition with a little lower amount of $\mathrm{V}$ was described by Weiser (1966) from chromite dikes from Outokumpu (see Vähätalo, 1953, page 39).

The chromite crystal in sample B 6379 (Fig. 4c, 4d) shows light and dark areas with sharp boundaries as al-

Table 2. Electron microprobe analyses of chromite.

\begin{tabular}{|c|c|c|c|}
\hline Analysis no. & 1 & 2 & 3 \\
\hline \multicolumn{4}{|c|}{ weight per cent } \\
\hline $\mathrm{Cr}_{2} \mathrm{O}_{3}$ & 52.27 & 68.74 & 54.63 \\
\hline $\mathrm{Al}_{2} \mathrm{O}_{3}$ & n.d. & n.d & 13.59 \\
\hline $\mathrm{V}_{2} \mathrm{O}_{3}$ & 14.93 & 0.37 & 0.37 \\
\hline $\mathrm{Fe}_{2} \mathrm{O}_{3}$ & 1.00 & 0.80 & 0.11 \\
\hline $\mathrm{FeO}$ & 24.73 & 16.43 & 12.92 \\
\hline $\mathrm{MgO}$ & n.d. & 5.14 & 7.96 \\
\hline $\mathrm{MnO}$ & 2.57 & 1.26 & 0.83 \\
\hline $\mathrm{ZnO}$ & 5.62 & 6.97 & 8.72 \\
\hline Total & 101.12 & 99.71 & 99.13 \\
\hline \multicolumn{4}{|c|}{ atomic proportions } \\
\hline $\mathrm{Cr}$ & 1.529 & 1.967 & 1.450 \\
\hline $\mathrm{Al}$ & -- & --- & 0.537 \\
\hline $\mathrm{V}$ & 0.443 & 0.011 & 0.010 \\
\hline $\mathrm{Fe}^{3+}$ & 0.028 & 0.028 & 0.003 \\
\hline $\mathrm{Fe}^{2+}$ & 0.766 & 0.498 & 0.362 \\
\hline $\mathrm{Mg}$ & -- & 0.277 & 0.398 \\
\hline $\mathrm{Mn}$ & 0.081 & 0.039 & 0.024 \\
\hline $\mathrm{Zn}$ & 0.153 & 0.186 & 0.216 \\
\hline
\end{tabular}

n.d.: not detected

1: homogeneous chromite (sample B 6384)

2: zoned chromite (light in BSE), (sample B 6397)

3: zoned chromite (dark in BSE), (sample B 6397) 
ready seen under the ore microscope. The light zones contain higher $\mathrm{Cr}$ (47.03 wt.\%) and $\mathrm{Fe}$ (13.34 wt.\%) contents than the darker zones $(38.15 \mathrm{wt} . \% \mathrm{Cr}$ and $10.12 \mathrm{wt} \%$ Fe, respectively). The light zones in BSE images are free from $\mathrm{Al}$ whereas the dark zones contain up to 7.19 wt.\% Al. The Mg content of the dark areas is with $4.80 \mathrm{wt} . \%$ only slightly higher than the content in the light zones $(3.10 \mathrm{wt} . \%)$. The $\mathrm{Zn}$ content of the chromite is $5.60 \mathrm{wt} . \%$ in the light and $7.00 \mathrm{wt} . \%$ in the dark zones. This is in good agreement with observations by Weiser (1966, 1967; Table 3) on chromite grains from the so-called parallel ore body (Vähätalo, 1953). The chromite also contains small amounts of $\mathrm{Mn}$, which is with 0.98 wt.\% slightly higher in the light zones than in the dark ones (0.64 wt.\%). Both types of zones have only small amounts of $\mathrm{V}$ (0.25 wt.\%). The calculated structural formula for the light zones is $\left(\mathrm{Fe}_{0.50} \mathrm{Mg}_{0.28} \mathrm{Zn}_{0.18} \mathrm{Mn}_{0.04}\right)_{1.00}$ $\left(\mathrm{Cr}_{1.97} \mathrm{Fe}_{0.02} \mathrm{~V}_{0.01}\right)_{2.00} \mathrm{O}_{4}$ and for the dark areas $\left(\mathrm{Mg}_{0.40} \mathrm{Fe}_{0.36} \mathrm{Zn}_{0.22} \mathrm{Mn}_{0.02}\right)_{1.00}\left(\mathrm{Cr}_{1.45} \mathrm{Al}_{0.54} \mathrm{~V}_{0.01}\right)_{2.00} \mathrm{O}_{4}$.

\subsubsection{Uraninite}

Euhedral chromite grains surrounded by a thucholite halo discovered in the specimen B 6384 are similar to those described by Wetherill et. al (1962) as uraninite inside thucholite balls. Uraninite has in average (9 analyses) 63.77 wt.\% U, 20.81 wt. $\% \mathrm{~Pb}$ and 0.08 wt.\% Th, 0.34 wt.\% Fe, 0.33 wt.\% Cu, 0.12 wt.\% $\mathrm{Bi}$, and 13.34 wt.\% O. The age estimates obtained for the uraninite are $\mathrm{U}^{238} / \mathrm{Pb}^{206} 1815 \mathrm{Ma}, \mathrm{U}^{235} / \mathrm{Pb}^{207}$ $1850 \mathrm{Ma}$, and $\mathrm{Pb}^{207} / \mathrm{Pb}^{206} 1885 \mathrm{Ma}$.

\subsubsection{Sulphosalts and Sulphides}

Willyamite could only be found in sample B 6379. The two grains contain 23.07 respectively $21.47 \mathrm{wt}$ \% $\%$ Co, 2.63 respectively $2.70 \mathrm{wt} . \% \mathrm{Ni}$ and 0.84 respectively 4.92 wt. $\%$ Fe. One grain also contains 0.59 wt. $\%$ Zn. The Sb content of 57.69 resp. 54.19 wt.\% is partly substituted by traces of As $(0.26-0.30 \mathrm{wt} . \%)$ and Te $(0.15-0.25$ wt.\%). The content of S lies at 15.10 respectively $16.01 \mathrm{wt} . \%$. The formulae of the two grains are $\left(\mathrm{Co}_{0.83} \mathrm{Ni}_{0.10} \mathrm{Fe}_{0.03} \mathrm{Zn}_{0.02}\right)_{0.98}\left(\mathrm{Sb}_{1.01} \mathrm{As}_{0.01}\right)_{1.02} \mathrm{~S}_{1.00}$ and $\left(\mathrm{Co}_{0.75} \mathrm{Ni}_{0.10} \mathrm{Fe}_{0.18}\right)_{1.03}\left(\mathrm{Sb}_{0.92} \mathrm{As}_{0.01}\right)_{0.93} \mathrm{~S}_{1.03}$ (Table 4, no. 3, no. 4).

Ullmannite of sample B 6384 contains, apart of the main elements $\mathrm{Ni}, \mathrm{S}$, and $\mathrm{Sb}$, small amounts of $\mathrm{Co}(2.77$ wt.\%) and traces of $\mathrm{Fe}(0.40$ wt. $\%)$ and $\mathrm{Cu}$ (0.34 wt.\%) substituting $\mathrm{Ni}$ and 0.37 wt.\% As substituting $\mathrm{Sb}$. The calculated formula is $\left(\mathrm{Ni}_{0.86} \mathrm{Co}_{0.10}\right.$ $\left.\mathrm{Fe}_{0.02} \mathrm{Cu}_{0.01}\right)_{0.99}\left(\mathrm{Sb}_{0.99} \mathrm{As}_{0.01}\right) \mathrm{S}_{1.00}$ (Table 4, no. 1). Ullmannite of sample B 6379 is characterised by small amounts of $\mathrm{Fe}(2.07$ wt.\%) and $\mathrm{Co}$ (2.63 wt.\%) substituting for $\mathrm{Ni}$ and $0.30 \mathrm{wt} . \%$ As substituting for $\mathrm{Sb}$. This corresponds to the formula $\left(\mathrm{Ni}_{0.87} \mathrm{Co}_{0.09} \mathrm{Fe}_{0.08}\right)_{1.04}$ $\left(\mathrm{Sb}_{0.98} \mathrm{As}_{0.01}\right)_{0.99} \mathrm{~S}_{0.97}$ (Table 4, no. 2).

Pyrrhotite of sample B 6384 contains between 0.40 and 0.53 wt. $\% \mathrm{Ni}$, but no Co. The Ni content of pyrrhotite with $0.33-0.38$ wt. $\%$ is slightly lower in sample B 6379.

The analysed grains of pentlandite of sample B 6384 have a very homogeneous composition with a mean Co content of 10.25 wt.\% (Table 4, no. 5) and the general formula $\left(\mathrm{Ni}_{4.10} \mathrm{Fe}_{3.63} \mathrm{Co}_{1.35}\right)_{9.08} \mathrm{~S}_{7.92}$. Pentlandite grains of sample B 6379 have Co contents between 12.40 and 13.64 wt.\% which are significantly higher than those in sample B 6384 (see Table 4). The Fe content varies between 24.89 and 25.78 wt.\% depending on the content of Co. The Ni content is very constant of around $28.51 \mathrm{wt} . \%$. This leads to the general formula of $\left(\mathrm{Fe}_{3.50} \mathrm{Ni}_{3.78} \mathrm{Co}_{1.78}\right)_{9.06} \mathrm{~S}_{7.94}$.

Sphalerite of sample B 6384 contains between 5.63 and 5.94 wt.\% Fe, traces of Co (0.32 wt.\%) and in some grains traces of $\mathrm{Cu}(0.25 \mathrm{wt} . \%)$, but no Cd. Sphalerite of sample B 6379 contains between 5.92 and 8.14 wt.\% Fe and always traces of Co up to 0.35 wt. $\%$, but no other significant elements, especially no cadmium. The average formula is $\left(\mathrm{Zn}_{0.90} \mathrm{Fe}_{0.11}\right)_{1.01} \mathrm{~S}_{0.99}$.

The measured grains of chalcopyrite of sample B 6384, including the inclusions in eskolaite, contain only $\mathrm{Cu}, \mathrm{Fe}$ and $\mathrm{S}$ in stoichiometric composition $\mathrm{CuFeS}_{2}$. All four measured grains of chalcopyrite of sample B 6379 also have a stoichiometric composition. Only one grain contains $0.23 \mathrm{wt} . \% \mathrm{Ni}$. 


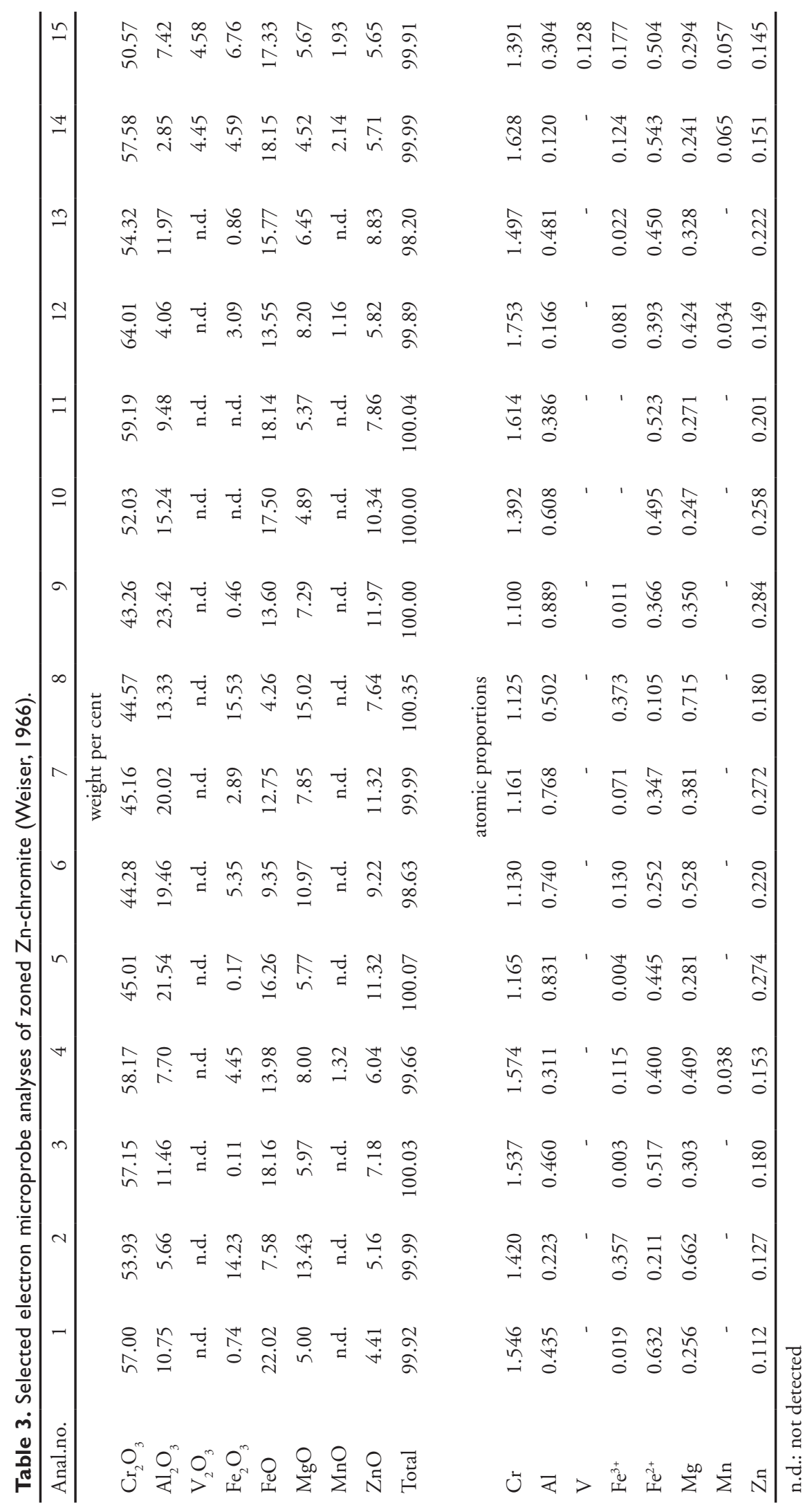


Table 4. Electron microprobe analyses of sulphides.

\begin{tabular}{|c|c|c|c|c|c|c|c|}
\hline Analysis no. & 1 & 2 & 3 & 4 & 5 & 6 & 7 \\
\hline \multicolumn{8}{|c|}{ weight per cent } \\
\hline $\mathrm{Fe}$ & 0.40 & 2.07 & 0.84 & 4.92 & 26.06 & 25.78 & 24.99 \\
\hline Co & 2.77 & 2.63 & 23.07 & 21.47 & 10.25 & 12.40 & 13.64 \\
\hline $\mathrm{Ni}$ & 23.60 & 24.15 & 2.63 & 2.70 & 30.94 & 28.95 & 28.44 \\
\hline $\mathrm{Cu}$ & 0.34 & n.d. & n.d. & n.d. & n.d. & n.d. & n.d. \\
\hline $\mathrm{Zn}$ & n.d. & n.d. & 0.59 & n.d. & n.d. & n.d. & n.d. \\
\hline$S$ & 15.15 & 14.71 & 15.10 & 16.01 & 32.50 & 32.81 & 32.78 \\
\hline As & 0.37 & 0.30 & 0.26 & 0.30 & n.d. & n.d. & n.d. \\
\hline $\mathrm{Te}$ & n.d. & n.d. & 0.15 & 0.23 & n.d. & n.d. & n.d. \\
\hline $\mathrm{Sb}$ & 56.89 & 56.32 & 57.69 & 54.19 & n.d. & n.d. & n.d. \\
\hline Total & 99.52 & 100.18 & 100.33 & 99.82 & 99.75 & 99.94 & 99.85 \\
\hline \multicolumn{8}{|c|}{ atomic proportions } \\
\hline $\mathrm{Fe}$ & 0.015 & 0.078 & 0.032 & 0.182 & 3.632 & 3.586 & 3.481 \\
\hline Co & 0.100 & 0.094 & 0.833 & 0.754 & 1.354 & 1.634 & 1.799 \\
\hline $\mathrm{Ni}$ & 0.858 & 0.870 & 0.095 & 0.095 & 4.102 & 3.832 & 3.768 \\
\hline $\mathrm{Cu}$ & 0.011 & --- & --- & --- & --- & --- & -- \\
\hline $\mathrm{Zn}$ & --- & --- & 0.019 & --- & 0.001 & --- & -- \\
\hline$S$ & 1.008 & 0.970 & 1.003 & 1.034 & 7.912 & 7.948 & 7.952 \\
\hline As & 0.011 & 0.008 & 0.007 & 0.008 & -.- & --- & -- \\
\hline $\mathrm{Te}$ & --. & --- & 0.003 & 0.004 & --- & --- & --. \\
\hline $\mathrm{Sb}$ & 0.997 & 0.978 & 1.008 & 0.921 & --- & -.- & --- \\
\hline
\end{tabular}

n.d.: not detected

1: ullmannite (sample B 6384); 2: ullmannite (sample B 6379); 3 and 4: willyamite (sample B 6379); 5: pentlandite (sample B 6384)

6: pentlandite, lowest Co content, (sample B 6579); 7: pentlandite, highest Co content, (sample B 6379)

\section{Discussion and conclusions}

The analyses of eskolaite grains of the present study and from previous studies are plotted in Fig. 7 in a ternary $\mathrm{Cr}_{2} \mathrm{O}_{3}-\mathrm{V}_{2} \mathrm{O}_{3}-\mathrm{Fe}_{2} \mathrm{O}_{3}$ diagram and in the $\mathrm{Cr}_{2} \mathrm{O}_{3}-$ $\mathrm{V} 2 \mathrm{O}_{3} \mathrm{XY}$-diagram. The present analysis points overlap the first analysis point of Kouvo and Vuorelainen (1958) and the points of von Knorring et al. (1986), but only partly overlap the analyses of Peltonen et al. (1996), which seem to have higher $\mathrm{V}_{2} \mathrm{O}_{3}$ contents. All the analyzed grains are from the Outokumpu ore body and its wall rocks, but from different mines. In the studied samples eskolaite occurs within the massive sulphide ore or in the tremolite skarn rocks rich in chromian skarn minerals (von Knorring et al. 1986). The grains analyzed by Peltonen et al. (1996) were taken from two drill core intersections of the Keretti mine, showing most of the eskolaite grains on the borders of the sulphide ore body in quartz rich wall rocks. The eskolaite grains from Keretti mine have exceptionally high $\mathrm{V}_{2} \mathrm{O}_{3}$ contents suggesting higher vanadium whole rock contents in the wall rocks than inside the massive sulphide ore. The eskolaite grains of this study occur together with silicates as inclusions in massive sulphides. The zoned eskolaite grains have trapped inclusions of chalcopyrite and pyrrhotite and veinlets and inclusions of silicates (Fig. 1a-f, 2a-f). The trapped sulphide inclusions suggest an ear- 

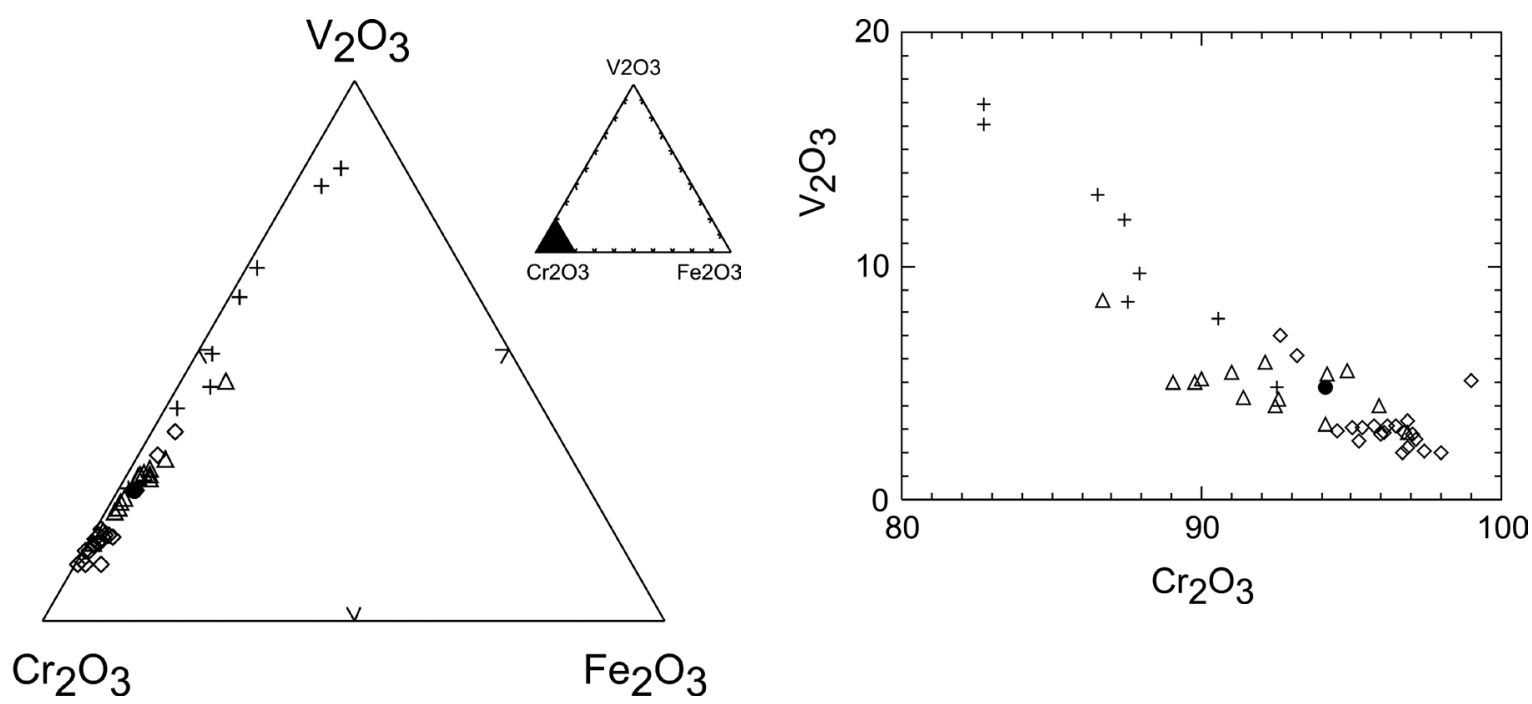

$\mathrm{Fe}_{2} \mathrm{O}_{3}$

Fig. 7. Ternary and XY-diagram of the eskolaite: triangles, this study; dot, Kouvo \& Vuorelainen (I958); diamonds, von Knorring et al. (1986); crosses, Peltonen et al. (1996).

ly formation of eskolaite in high temperature. Peltonen et al. (1996) consider, however, eskolaite as a metamorphic mineral that has formed in a pressure of $3-5 \mathrm{~kb}$ and temperature of ca. $580-640^{\circ} \mathrm{C}$.

Eskolaite is isostructural with corundum, hematite and karelianite. The experimental studies of the systems eskolaite-corundum and eskolaite-hematite have shown a complete solid solution at high temperatures $\left(>1100^{\circ} \mathrm{C}\right)$. With decreasing temperatures the solid solution field breaks up to form a miscibility gap, and the natural eskolaite and corundum have only small amounts of $\mathrm{Al}$ and $\mathrm{Cr}$, respectively (Barks \& Roy, 1972; Chatterjee et al., 1982). According to these experimental studies, eskolaite contains about $25 \mathrm{~mol} . \% \mathrm{Al}_{2} \mathrm{O}_{3}$ at $580^{\circ} \mathrm{C}$, which decreases to a few percent close to $200^{\circ} \mathrm{C}$. The pressure dependence of the solvus is very small allowing the use of eskolaite composition as a geological thermometer. The maximum $\mathrm{Al}_{2} \mathrm{O}_{3}$ content of the analyzed eskolaite grains is 5.9 wt.\% (Table 1, anal. no. 7, Fig. 2 b) corresponding approximately to an equilibration temperature of $430^{\circ} \mathrm{C}$. However, the same analysis also shows 5.0 wt. $\% \mathrm{~V}_{2} \mathrm{O}_{3}$. If this is added to $\mathrm{Al}_{2} \mathrm{O}_{3}$, the crystallization temperature is $\mathrm{ca} .600^{\circ} \mathrm{C}$. The zoned grains of eskolaite reflect changes in the crystallization tem- peratures. The light zones (Fig. 1a-f, 2a-f) in the rim, showing the lowest $\mathrm{Al}$ contents (Table 1, anal. no. $4,8,12,14$, Figures $1 \mathrm{a} / 2 \mathrm{a}, 1 \mathrm{~b} / 2 \mathrm{~b}$ and $1 \mathrm{f} / 2 \mathrm{f}$ ), correspond to the lowest temperatures of crystallization at around $400^{\circ} \mathrm{C}$. Finally, the eskolaite grains have been hydrothermally replaced by silicates. The relationship between hematite and eskolaite is probably similar, because in nature eskolaite has only low contents of $\mathrm{Fe}_{2} \mathrm{O}_{3}$. In the Outokumpu sulphide ore and skarns, eskolaite is the only existing mineral of this group reflecting the high $\mathrm{Cr}$ content. Chromium has distributed in several phases including chromite, eskolaite, uvarovite, chrome-diopside and chromian tremolite (von Knorring et al., 1986). Both the sulphide ore and the skarns have undergone one or several metamorphic-metasomatic events (polymetamorphism). According to Treloar et al. (1981), the garnet-cordierite thermometry in the Outokumpu area gives $600 \pm 50^{\circ} \mathrm{C}(\mathrm{P}=3.5 \pm 1 \mathrm{~kb})$. Olivine-spinel thermometry gives a temperature of $630-640^{\circ} \mathrm{C}$ (Peltonen et al., 1996). These temperatures are in the field of the monosulphide solid solution and high enough to enable extensive diffusion and vapour activity between the sulphide, silicate and oxides phases. 
Primary magmatic chromian spinel phases have crystallized before the sulphide melt, and they have changed their composition near the cooling sulphides (Fig. 8). This explains the formation of the homogenous $\mathrm{Zn}$ rich chromite, in which part of the $2^{+}$valence elements have been replaced by $\mathrm{Zn}$ originally present in sphalerite of the sulphide ore (Table 2, anal. no. 1, Fig. 4a, 4b). Liipo et al. (1995) also suggest that the large amount of $\mathrm{Cu}-\mathrm{Co}-\mathrm{Zn}$-Au ore is the source of the $\mathrm{Zn}$ in the chromite. The zoned $\mathrm{Zn}$-bearing chromite represents a further metasomatized variation with high $\mathrm{Zn}$ in the core and increasing $\mathrm{Fe}, \mathrm{Al}$ and $\mathrm{Mg}$ contents in the rims due to reaction with surrounding silicates (Table 2, anal. no. 2 and 3, Fig. 4c, 4d). Von Knorring et al. (1986) list several types of chromite from diopside-tremolite skarns, chromite dykelets crosscutting the skarns, from a chromite band in uvarovite-tremolite skarn, in dolomite, with uvarovite and enclosed in uvarovite crystals.

Ullmannite and willyamite form a solid solution NiSbS-CoSbS (Dobbe, 1991). In the Hultebo deposit, Tunaberg, Bergslagen, central Sweden, cobaltian willyamite is rimmed by willyamite indicating a later crystallisation of willyamite. Dobbe (1991) sug-

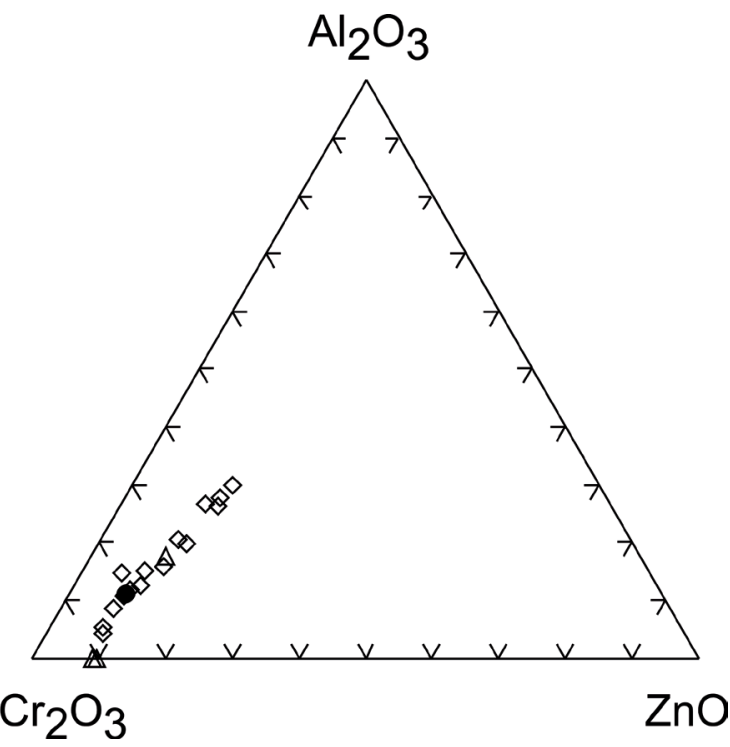

gest that the crystallization of ullmannite is followed by cobaltian ullmannite and willyamite solid solution during cooling of the hydrothermal solution. Bayliss (1969) synthesized solid solutions in the cubic (Ni,Co)SbS series at $550^{\circ} \mathrm{C}$, but not the end member willyamite CoSbS. Dobbe (1991) assumes a miscibility gap in ullmannite-willyamite series below $550^{\circ} \mathrm{C}$, similar to that of gersdorffite-cobaltite. In the present study, the grains of ullmannite and willyamite in the sulphide ore samples of Outokumpu are not intergrown with each other, and no conclusions of their mutual crystallization sequence can be done.

\section{Acknowledgements}

We would like to thank Professor M. Lehtinen from the Natural history museum of the University of Helsinki for putting the samples for examination to the disposal of the senior author. We are grateful to Dr. T. Oberthür for stimulating discussions and helpful comments. Mr. Bo Johanson is thanked for the analyses of uraninite. Dr. F. Melcher is thanked for technical support at the photomicrographs. Critical reviews by the chief editor Dr. P. Peltonen and Dr. O.A.R. Thalhammer improved the manuscript.

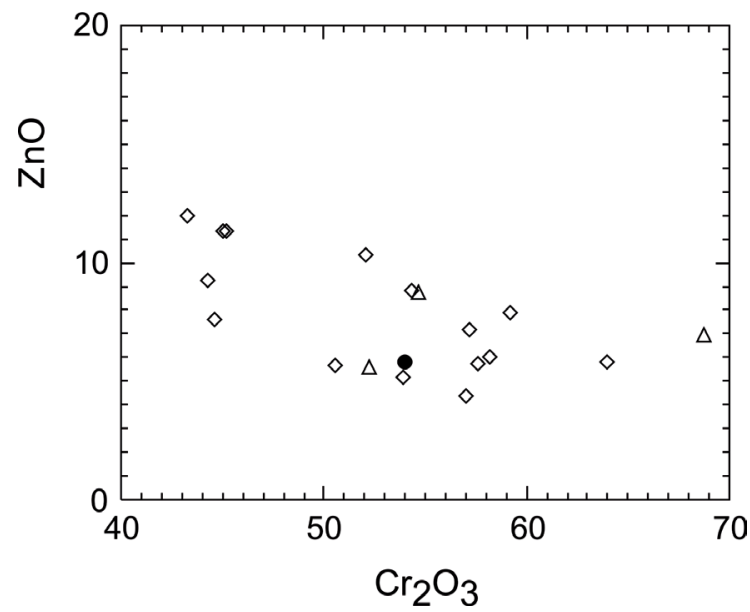

Fig. 8. Ternary and XY-diagram of Zn-bearing chromite: triangles, this study; dot, Thayer et al. (1964); diamonds, Weiser $(1966,1967)$. 


\section{References}

Barks, R.E. \& Roy, D.M., 1972. Subsolidus phase equilibria in $\mathrm{Al}_{2} \mathrm{O}_{3}-\mathrm{Cr}_{2} \mathrm{O}_{3}$. Nature 235, 118-119.

Bayliss, P., 1969. Isomorphous substitution in synthetic cobaltite and ullmannite. American Mineralogist 54, 426-430.

Cassedanne, Ja. \& Cassedanne, Je., 1980. Présence d'eskolaite dans les alluvions stanniferes de la Chapada Diamantina (Bahia-Brésil). Bulletin de Minéralogie, 103, 600-602.

Chatterjee, N.D., Leistner, H., Terhart, L., Abraham, K. \& Klaska, R., 1982. Thermodynamic mixing properties of corundum-eskolaite, a- $\left(\mathrm{Al}, \mathrm{Cr}^{3+}\right)_{2} \mathrm{O}_{3}$, crystalline solid solutions at high temperatures and pressures. American Mineralogist 67, 725-735.

Dobbe, R.T.M., 1991. Ullmannite, cobaltian ullmannite and willyamite from Tunaberg, Bergslagen, Central Sweden. Canadian Mineralogist 29, 199-205.

Forster, I.F., 1960. Beobachtungen an einem primären Goldvorkommen in ultrabasischen Gesteinen des Lowvelds (Nordost Transvaal, S.A.). Neues Jahrbuch für Mineralogie, Abhandlungen 94, 228-266.

Karpenko, V.Ju. \& Tištšenko, A.I., 1992. Eskolaite in aleurosandstone of the Urzugian suite in the northwestern Belomorides. Mineralogicheskiy Zhurnal 14, 93-96 (in Russian with English summary).

Knorring, O.von, Condliffe, E. \& Tong, Y.L., 1986. Some mineralogical and geochemical aspects of chromiumbearing skarn minerals from northern Karelia, Finland. Bulletin of the Geological Society of Finland 58, 277-292.

Kouvo, O. \& Vuorelainen, Y., 1958. Eskolaite, a new chromium mineral. American Mineralogist 43, 1098-1106.

Liipo, J., Vuollo, J., Nykänen, V., Piirainen, T., Pekkarinen, L. \& Tuokko, I., 1995. Chromites from the early Proterozoic Outokumpu-Jormua Ophiolite Belt: a comparison with chromites from Mesozoic ophiolites. Lithos 36, 15-27.

Milton, C. \& Chao, E.C.T., 1958. Eskolaite, $\mathrm{Cr}_{2} \mathrm{O}_{3}$, in "merumite" from British Guiana. American Mineralogist 43, p. 1203.

Milton, C. \& Narain, S., 1969. Merumite occurrence in Guyana. Economic Geology, 64, 910-914.

Oppenheim, M.J., Brück, P.M., Elsdon, R., Synge, F.M., Weaver, A. \& Warren, W.P., 1977. Eskolaite, $\mathrm{Cr}_{2} \mathrm{O}_{3}$, from County Wicklow, Ireland. Mineralogical Magazine 41, 402-403.

Peltonen, P., Kontinen, A. \& Johanson, B., 1996. Eskolaiitin koostumuksesta. In: Peltonen, P., Korsman, K. \& Salminen, R. (eds.) Tutkimuksia geologian alalta. Annales Universitatis Turkuensis, SER. C OSA, TOM 126, 109-116.

Thayer, T.P., Milton, C., Dinnin, J. \& Rose, H. jr., 1964. Zincian chromite from Outokumpu, Finland. American Mineralogist 49, 1178-1183.
Treloar, P.J., Koistinen, T.J. \& Bowes, D.R., 1981. Metamorphic development of cordierite - amphibole rocks and mica schists in the vicinity of the Outokumpu ore deposit, Finland. Transactions Royal Society Edinburgh Earth Sciences 72, 201-215.

Vähätalo, V.O., 1953. On the geology of the Outokumpu ore deposit in Finland. Bulletin de la Commission géologique de Finlande 164, 94 p.

Weiser, T., 1966. Geochemischen Untersuchungen an Chromiten mit der Elektronenmikrosonde. Ph. D. thesis, Ludwig-Maximilians-Universität München, Germany, $91 \mathrm{p}$.

Weiser, T., 1967. Zink- und Vanadium-führende Chromite von Outokumpu/Finnland. Neues Jahrbuch für Mineralogie, Monatshefte 1967 (7/8), 234-243.

Wetherill, G., Kouvo, O., Tilton, G. \& Gast, P., 1962. Age measurements of rocks from the Finnish Precambrian. Journal of Geology 70, 74-88. 